RESEARCH ARTICLES

\title{
The Effect of the Achievement Motivations On Sport Character: An Investigation On Elite Athletes
}

\section{El efecto de las motivaciones de logro en el carácter deportivo: una investigación sobre atletas de élite}

\author{
Yasin Yildiz \\ Aydin Adnan Menderes Universtiy, Faculty of Sports Sciences, Turkey \\ Orcid id: 0000-0003-3230-5717 \\ Mevlüt Yildiz \\ Mugla Sitki Kocman University, Faculty of Sport Sciences, Turkey \\ Orcid id: 0000-0002-1910-0330 \\ Erkan Bingöl \\ Vocational School Koycegiz, Mugla Sitki Kocman University, Turkey \\ Orcid id: 0000-0001-9425-4623
}

Received 08-12-20 Revised 09-30-20

* Correspondence

Email: yasin.yildiz@adu.edu.tr
Accepted 10-13-20 On line 01-14-21

Citation:

Yasin Yildiz, Mevlüt Yildiz, Erkan Bingöl. (2021). The Effect of the Achievement Motivations On Sport Character: An Investigation On Elite Athletes. Propósitos y Representaciones, 9(SPE1), e1225. Doi: http://dx.doi.org/10.20511/pyr2021.v9nSPE1.e1225 


\section{Summary}

This study aimed to evaluate the sport character orientation of elite athletes in different branches of Turkish National Teams in terms of their achievement motivation. Two scales were used to obtain data for this study. To measure the sport character of the athletes, the "Sport Character Scale" developed by Chang-Yong Jang (2013) and adapted to Turkish by Görült and Tuncel (2017) was used. The "Sports-Specific Achievement Motivation Scale" developed by Willis (1982) and adapted to Turkish by Tiryaki and Gödelek (1997) was used to measure the motivation of athletes' success. Descriptive statistics, normality tests, correlation analysis, and multiple regression analyzes were performed by using the SPSS 25.0 package program in the analyses of the data. According to demographic findings, the majority of 223 athletes participating in the study were male athletes $(70.9 \%)$. The majority of athletes $(54.7 \%)$ were $21-24$ years old, $79.8 \%$ of them were interested in team sports; $43.5 \%$ of them were national athletes between 4-6 years. In addition, the majority of the athletes (33.2\%) had the best Balkan Ranking. The normality test results revealed that skewnesskurtosis coefficients of the variables were between \pm 3.0 and showed a normal distribution. The mean of the variables was " 2.54 " to "4.17"; the standard deviation was between " 0.55 " and " 1.02 ". Multiple regression analysis results showed that the relationship between variables was statistically significant $(\mathrm{p}<0.01)$. As a result, this study showed that there is a statistically significant relationship between sport character and "self-confidence", "motive to achieve success", "power motive", and "external factor approach". In addition, it was observed that "motive to achieve success" and "power motive" predicted the sport character by approximately $38 \%$.

Key words: Sport Character, Achievement, Motivation

\section{Resumen}

Este estudio tuvo como objetivo evaluar la orientación del carácter deportivo de los atletas de élite en diferentes ramas de los equipos nacionales turcos en términos de su motivación de logro. Se utilizaron dos escalas para obtener datos para este estudio. Para medir el carácter deportivo de los deportistas se utilizó la "Escala de carácter deportivo" desarrollada por Chang-Yong Jang (2013) y adaptada al turco por Görült y Tuncel (2017). Para medir la motivación del éxito de los atletas se utilizó la "Escala de motivación de logros específicos para deportes" desarrollada por Willis (1982) y adaptada al turco por Tiryaki y Gödelek (1997). Se realizaron estadísticas descriptivas, pruebas de normalidad, análisis de correlación y análisis de regresión múltiple utilizando el programa de paquete SPSS 25.0 en los análisis de los datos. Según los hallazgos demográficos, la mayoría de los 223 atletas que participaron en el estudio eran hombres (70,9\%). La mayoría de los deportistas $(54,7 \%)$ tenían entre 21 y 24 años, el 79,8\% de ellos estaban interesados en los deportes de equipo; El 43,5\% de ellos eran deportistas nacionales entre 4-6 años. Además, la mayoría de los deportistas $(33,2 \%)$ tuvo el mejor Ranking Balcánico. Los resultados de la prueba de normalidad revelaron que los coeficientes de asimetría-curtosis de las variables estuvieron entre \pm 3.0 y mostraron una distribución normal. La media de las variables fue de "2,54" a "4,17"; la desviación estándar estuvo entre " 0.55 ” “ "1. 02 ”. Los resultados del análisis de regresión múltiple mostraron que la relación entre las variables fue estadísticamente significativa $(\mathrm{p}<0.01)$. Como resultado, este estudio mostró que existe una relación estadísticamente significativa entre el carácter deportivo y la "confianza en uno mismo", "motivo para lograr el éxito", "motivo de poder" y "enfoque de factor externo". Además, se observó que "motivo para lograr el éxito" y "motivo de poder" predijeron el carácter deportivo en aproximadamente un $38 \%$.

Palabras clave: Carácter deportivo, Logro, Motivación.

\section{Introduction}

Factors such as politics, business world, education, social environment, religion, and entertainment play an important role in influencing the nature and quality (positive or negative) of human interactions along with the character (personalities) of individuals. Undoubtedly, a person's 
character is an important part of who the person is and how that person interacts with others (Doty, 2006).

Individuals encounter many positive or negative situations throughout their lives, and they react differently to these situations. The character that the person has is underlying these reactions. The character is shaped by an individual's adoption of the value judgments of the society he/she lives in since his/her childhood (Yıldiz, 2019). Character is a multidimensional phenomenon and is defined as "to have appropriate virtues for moral love and behavior, including psychological and behavioral qualities that allow the individual to show good morality in the face of events" (Teo, 2010). If evaluated from a different perspective, when the character is considered in terms of sports, it can be thought that these two concepts are not very far from each other.

Sport is a disciplined process, which has its own set of rules, including the physical activity function, as well as the socialization and social adaptation process. It is possible to be successful in sports only by following the rules. An athlete who successfully continues the adaptation process gains new features and behavior or improves his/her existing qualities.

Sports help shape the character of the athlete and teach how to compete. Team sports improve collaboration, while individual sports improve discipline (Tamminen et al., 2012). Certain sports that are considered dangerous increase the courage of the athlete. Some sports have high communication values. This is more evident especially in sports with physical contact, for example in combat sports. Sport teaches to evacuate aggressive impulses naturally and by following social rules (Gee, 2010).

In the literature, there are also popular opinions that sports support the character positively (Kavussanu and Roberts, 2001; Sage, 1990; Sage and Kavussanu, 2007). In this context, sports are considered as a tool for collaboration with teammates, finding solutions to negotiations and moral conflicts, justice, sportsmanship, team loyalty, teamwork, responsibility, and subjugation for greater well-being (Jang, 2013). The positive shape of the sport character in the sport is compatible with values such as being fair, compassionate, honest, and social. Besides, it strengthens the assumption that it will help the beginning of the professionalization process or the regular and efficient progress of the long sports life in combating the problems that will arise in the fields of sports (Görgüt and Tuncel, 2017).

Sport, by its nature, creates a social environment that enables individuals to communicate, interact and establish relationships with each other in order to provide athletes' sportive motivation with both their character and mental skills (Kavussanu, 2008). Therefore, examining the motivating effect of sport characters and intelligence dimensions of athletes in different branches and categories on sports achievement will contribute to some sports gains that can be described as important behavioral developments of athletes in today's sports.

This research was carried out to investigate the relationships between elite athletes' motivations for success and their sport characters.

\section{Materials and Method}

This study aimed to evaluate the sport characters and achievement motivation orientations of Turkish National Team athletes who are active in different branches, in addition, to examine the relationships between the achievement motivations and sport characters. In this context, in this section of the study, explanations about the research model, universe and sample, data collection method and tools and statistical analysis are given.

\section{Research model}

A quantitative research model was used in the research, the survey was used as a research method, and a questionnaire was used as a data collection tool in the research.

\section{Research group}


In the 2019-2020 season, 223 national athletes ( $n=158$ male $n=65$ female) actively involved in different sports branches of various Sports Federations of Turkey formed the research group of this study.

\section{Data collection method}

The available information on the purpose of the research has been systematically prepared by scanning the literature. In this context, the Sport Character Scale and the Sports-Specific Achievement Motivation Scale were applied to the participants along with the personal information form for demographic features. The questionnaires were distributed first and then the athletes who participated in the study were given information about the importance of the research and the importance they carry for this research. In addition, it was conveyed to athletes that giving correct and sincere answers may affect the reliability of the research. Only 275 of the 300 forms distributed during the survey application returned. Incorrect or incomplete questionnaire forms were excluded from the study and a total of 223 questionnaire forms were accepted for statistics and evaluated.

\section{Personal information form}

The 5-question personal information form, consisting of gender, age, sports branch, tenure as a national athlete, achievements in international tournaments, was used to determine the demographic characteristics of the participants.

\section{Measurement instruments}

\section{Sport Character Scale}

Sport Character Scale was developed by Chang-Yong Jang (2013) and adapted to Turkish by Görgüt and Tuncel (2017). Five items $(11,12,13,14$, and 15) of the 27-item scale consist of negative statements. Scale items were measured with a 5-point Likert rating. As a result of the reliability study, the researchers found the internal consistency coefficient of the scale to be 0.90 for the total of the scale. Internal consistency coefficients for five sub-dimensions of the scale were found 0.81 , $0.78,0.76,0.78,0.84$, respectively.

\section{Sports-Specific Achievement Motivation Scale}

Sports-Specific Achievement Motivation Scale was developed by Willis (1982) and adapted to Turkish by Tiryaki and Gödelek (1997). This scale consists of a total of 40 items. Items of this scale, which is a 5-point Likert type, are scored between 1 and 5. In reliability analyzes made by Tiryaki and Gödelek (1997), the internal consistency coefficients of the scale were calculated separately. As a result of the analysis, the reliability coefficients of the subscales were found to be " $\alpha=0.81$ " for the power motive subscale, " $\alpha=0.82$ " for the motive to achieve success subscale, and " $\alpha=0.80$ " for the motive to avoid failure subscale.

\section{Statistical analyses}

The research findings were obtained as a result of the analyzes carried out by transferring the data obtained from the participants to the SPSS 25.0 package program (Statistical Package for the Social Sciences). The data were analyzed based on the responses of 223 participants.

The reliability of the scales was calculated with Cronbach's Alpha coefficient. The distribution of the data was determined by Skewness and Kurtosis values.

The relationships between the variables were determined by Pearson correlation coefficient. Then, Multiple Regression Analysis was used to determine the effect of the independent variable on the dependent variable in accordance with the research model. This analysis is based on the Baron and Kenny Model. 


\section{Normal distribution analysis}

The normality of the distribution of the data of the scales was revealed by examining SkewnessKurtosis values and P-P Plot graphs. One of the methods used to evaluate univariate normality in statistics is to examine skewness and kurtosis coefficients. If these values are between \pm 3.0 , it is evaluated that the data distribution does not show an excessive deviation from normality (Qin, Leung, and Shao, 2002).

Skewness and Kurtosis values of the scales are presented in Table 1. According to the test result; variables were found to have a value between \pm 3.0 and showed normal distribution. Therefore, the parametric techniques were used in the analysis.

Table 1. Normality test results $(\mathrm{n}=223)$

\begin{tabular}{|c|c|c|}
\hline Variables & Skewness & Kurtosis \\
\hline Sport character & -.538 & .046 \\
\hline Self-confidence & -.373 & -.830 \\
\hline Motive to achieve success & -1.073 & .875 \\
\hline Power motive & -.882 & .770 \\
\hline Motive to avoid failure & .434 & -.497 \\
\hline External factor approach & -.367 & -.808 \\
\hline
\end{tabular}

\section{Results}

In this section, the findings regarding the success motivations of elite athletes and sport character orientations are presented.

\section{Descriptive analysis results for the demographic features of athletes}

Table 2. Demographic features of athletes

\begin{tabular}{|c|c|c|c|}
\hline Variables & Categories & f & $\%$ \\
\hline \multirow[t]{2}{*}{ Gender } & Female & 65 & 29.1 \\
\hline & Male & 158 & 70.9 \\
\hline \multirow[t]{3}{*}{ Age } & Between 17-20 & 81 & 36.3 \\
\hline & Between 21-24 & 122 & 54.7 \\
\hline & More than 25 & 20 & 9.0 \\
\hline \multirow[t]{2}{*}{ Sport branches } & Team sports & 178 & 79.8 \\
\hline & Individual sports & 45 & 20.2 \\
\hline \multirow[t]{4}{*}{ Tenure as a national athlete } & Between 1-3 years & 78 & 35.0 \\
\hline & Between 4-6 years & 97 & 43.5 \\
\hline & Between 7-9 years & 37 & 16.6 \\
\hline & 10 years and more & 11 & 4.9 \\
\hline \multirow{8}{*}{$\begin{array}{l}\text { Best degrees won in championships, tournaments } \\
\text { or Olympic games }\end{array}$} & No & 10 & 4.5 \\
\hline & Olympic degree & 3 & 1.3 \\
\hline & World degree & 36 & 16.1 \\
\hline & European degree & 59 & 26.5 \\
\hline & Universiade & 6 & 2.7 \\
\hline & Balkan degree & 74 & 33.2 \\
\hline & National degree & 31 & 13.9 \\
\hline & Others & 4 & 1.8 \\
\hline
\end{tabular}

Table 2 presents demographic findings regarding 223 athletes. $70.9 \%$ of the participants are male and $29.1 \%$ are female. Most of the participants are between the ages of 21 and 24 (54.7\%); $79.8 \%$ are interested in team sports; $43.5 \%$ have a tenure as a national athlete between $4-6$ years and $33.2 \%$ have the best Balkan degree achieved.

Table 3. Mean, standard deviation and correlation coefficients of the variables

\begin{tabular}{|l|l|l|l|l|l|l|l|}
\hline Variables & $\mathbf{X}$ & Sd & $\mathbf{1}$ & $\mathbf{2}$ & $\mathbf{3}$ & $\mathbf{4}$ & $\mathbf{5}$ \\
\hline
\end{tabular}




\begin{tabular}{|c|c|c|c|c|c|c|c|}
\hline $\begin{array}{c}\text { Sport } \\
\text { character }\end{array}$ & 4.0385 & .55142 & 1 & & & & \\
\hline $\begin{array}{c}\text { Self- } \\
\text { confidence }\end{array}$ & 3.4365 & 1.02524 & $.275^{* *}$ & 1 & & & \\
\hline $\begin{array}{l}\text { Motive to } \\
\text { achieve } \\
\text { success }\end{array}$ & 4.1787 & .69352 & $.536^{* * *}$ & $.319^{* * *}$ & 1 & & \\
\hline $\begin{array}{l}\text { Power } \\
\text { motive }\end{array}$ & 3.9933 & .73561 & $.536^{* *}$ & .057 & $.585^{* *}$ & 1 & \\
\hline $\begin{array}{l}\text { Motive to } \\
\text { avoid failure }\end{array}$ & 2.5433 & .86262 & -.077 & $.357^{* * *}$ & $-.283^{* *}$ & $-.317^{* *}$ & 1 \\
\hline $\begin{array}{l}\text { External } \\
\text { factor } \\
\text { approach }\end{array}$ & 3.8049 & .96857 & $.230^{* * *}$ & .031 & $.439^{* * *}$ & $.403^{* *}$ & $\overline{-}^{-}$ \\
\hline
\end{tabular}

$* * \mathrm{p}<0.01$

Table 3 shows the mean and standard deviation values, and correlation analysis of the variables. The arithmetic mean of the variables is between 2.54 and 4.17; standard deviation values range from 0.55 to 1.02 .

According to the findings, there are significant and positive correlations between the sport character of elite athletes and self-confidence $\left(\mathrm{r}_{(223)}=.27\right.$, p<0.001) $)$, motive to achieve success $\left(\mathrm{r}_{(223)=}\right.$ $.53, \mathrm{p}<0.001)$ ), power motive $\left(\mathrm{r}_{(223)=.53, \mathrm{p}<0.001)}\right)$, and external factor approach $\left(\mathrm{r}_{(223)=.23, \mathrm{p}<0.001)}\right)$. However, there is no significant relationship between sport character and motive to avoid failure $\left(r_{(223)}=-07, p=\right.$ $.253)$ ).

Table 4. Results of multiple regression analysis

\begin{tabular}{|c|c|c|c|c|c|}
\hline Variables & Unstandardized $\beta$ & $\begin{array}{l}\text { Unstandardized } \\
\text { Std. Error }\end{array}$ & $\begin{array}{c}\text { Standardized } \\
\beta\end{array}$ & $\mathbf{P}$ & $\mathbf{F}$ \\
\hline Constant & 1.581 & .252 & - & .000 & \\
\hline $\begin{array}{c}\text { Self- } \\
\text { confidence }\end{array}$ & .069 & .035 & $.128^{*}$ & .047 & \\
\hline $\begin{array}{c}\text { Motive to } \\
\text { achieve } \\
\text { success }\end{array}$ & .246 & .060 & $.310^{* *}$ & .000 & $28.220^{* *}$ \\
\hline Power motive & .294 & .051 & $.392^{* *}$ & .000 & \\
\hline $\begin{array}{c}\text { Motive to } \\
\text { avoid failure }\end{array}$ & .049 & .041 & .077 & .228 & \\
\hline $\begin{array}{c}\text { External } \\
\text { factor } \\
\text { approach }\end{array}$ & -.028 & .034 & -.050 & .411 & \\
\hline
\end{tabular}

Table 4 indicates that the results of multiple regression analyses are statistically significant $(\mathrm{F}=28.220, \mathrm{p}<0.001)$. The adjusted $\mathrm{R}^{2}$ value is 0.38 . This value shows that the $38 \%$ variance of the sport character is explained by self-confidence, motive to achieve success, power motive, motive to avoid failure, and external factor approach. However, when the beta coefficients of the variables in the regression model are examined, it is seen that the self-confidence $(\beta=0.12, p<0.05)$, motive to achieve success $(\beta=0.31, \mathrm{p}<0.01)$, and power motive $(\beta=0.39, \mathrm{p}<0.01)$ significantly explains the sport character. On the other hand, it is seen that the motive to avoid failure $(\beta=0.07, p>0.05)$ and external factor approach $(\beta=-0.05, p>0.05)$ do not have any significant contribution on the dependent variable.

\section{Discussion and Conclusion}

This research aimed to evaluate the sport character orientations of elite athletes in different branches in terms of their success motivations in Turkish National Teams. In this context, the research findings and the results in the literature are discussed in this section. 
Many people in the community believe that participating in sport and physical activity programs automatically improve character, strengthens the moral judgment, and brings good sports behavior, but few sources in the literature support this belief (Hodge, 1989). Participating in sports and physical activities do not directly reveal to good or bad individuals. It is not possible to say that a character is reached with these activities, but some things can be taught. In this context, teaching individuals moral judgment and good sports behavior becomes possible with the systematic use of certain strategies (Weinberg and Gould, 2015). An athlete cannot achieve a certain character through sports training or physical activity, but the athlete can be taught how to develop the character.

The characteristics and personality characteristics of the athletes can be effective in their tendency to the sports branch which they perform. Today, it is observed that individuals participating in sports activities have undergone some changes in their characteristic features with the effect of their branch. It is known that individuals differ from each other in terms of their physical appearance as well as their attitude and behavior. The attitudes and behaviors of individuals in the face of developing events show that they differ from each other in terms of their feelings and ideas (Eren, 2001). The phenomenon of sports is generally based on the concept of "highest performance". Therefore, an athlete must be ready to reach the highest performance by using all his powers, spiritual and physical characteristics. Hence, in order for the athlete to achieve high performance, he/she must have a personality structure that is suitable for making all the sacrifices required (Akın, 2015).

According to the results of our research, in which 223 athletes participated, $70.9 \%$ of the participants were male and $29.1 \%$ were female. Most of the participants were between the ages of 21 and $24(54.7 \%) ; 79.8 \%$ were interested in team sports; $43.5 \%$ had a tenure as a national athlete between 4-6 years and $33.2 \%$ had the best Balkan degree achieved.

The results of our research showed that there was a positive relationship between the variables and the variables change together. In other words, variables other than "motive to avoid failure" had undergone a change with the variable of sport character. According to these results, it can be said that achievement is one of the important factors affecting the sport character.

John Wooden, a successful basketball coach, has clearly stated the importance of the character and his influence on the individual with the words "talent will get you to the top, but it takes character to keep you there." In addition to this thought, he also stated that gaining fame should not exceed the character. He explained the reason for this as "the reputation we earn is what people think about us, and the character is the person we actually exist" (Wooden and Jamison, 1997).

Coakley (2001) stated that sports behavior may differ from real life, or it may be a situation that imitates real life. Therefore, it is thought that the character that may arise during daily life and the character in sportive life may differ from each other.

Whether success and motivation have a positive or negative effect on one's character is shaped by the "situational conditions" and "individual factors" that the person experiences.

Today, sports perception has become a "success-oriented" situation. The focus on success in sports affects the thoughts, behaviors, and characters of the athletes, which causes changes in such characteristics of the athletes. In sports literature, it is accepted that the climate created by sports has an impact on the athlete's character. It is emphasized that success or failure in sports activities have many positive or negative effects on the characters of athletes. Along with the idea that success affects the sport character positively, Balçıkanlı (2017) stated that there are some sources emphasizing that competitive sports have negative effects on sport character development.

Hellison (2003), in his research, found that creating positive characters is not related to participation in sports. In addition, in other researches, it was found that the deliberate violation of the rules during the sports game or competition was caused by the lack of character, while those with character deficiencies acted aggressively against their opponents (Dunn and Dunn, 1999; Silver, 1983). 
As a result of the research, it is thought that the development of sport characters and selfconfidence of the athletes contributed positively to their motivation in achieving the targeted sport's success.

Features such as goal setting, time management, sequential thinking, initiative, concentration, attention, and focus are among the basic features of sports performance. Such features and trends that make up the sports performance can provide the athlete, the coach, and even the parents, a great advantage in the process leading to success. However, further research is needed to further investigate the assumed links and to determine the potential mediating effects of other variables such as the sports branch. We believe that our study will lead the next researches to be done in order to further clarify the concepts of sports and characters and to clarify their theoretical frameworks, both in terms of theory and practice.

\section{References}

Akın, T. (2015). Futbol oyuncularının ego durumlarıyla takımlardaki pozisyonlarının uyuşma bağdaşıklık düzeyinin saha içi performansları ile ilişkisi (Master's Thesis), Istanbul Arel Üniversitesi Sosyal Bilimler Enstitüsü.

Balçıkanlı, G.S. (2017). Yarı̧̧ma sporlarının ahlaksal amacı. Spor ve Performans Araştırmaları Dergisi, 8(1), 47-52.

Büyüköztürk, Ş. (2010). Sosyal bilimler için veri analizi el kitabı. Ankara: Pegem Akademi Yayınları.

Coakley, J. (2001). Sport in society. St Louis, MO: C.V. Mosby Co.

Doty, J. (2006). Sports build character?!. Journal of College and Character, 7(3), 2-4.

Dunn, J.G., \& Dunn, J.C. (1999). Goal orientations, perceptions of aggression, and sportspersonship in elite male youth ice hockey players. The Sport Psychologist, 13, 183-200.

Eren, E. (2001). Örgütsel davranış ve yönetim psikolojisi (7. Baskı). Istanbul: Beta.

Gee, C.J. (2010). How does sport psychology actually improve athletic performance? a framework to facilitate athletes' and coaches' understanding. Behavior Modification, 34 (5), 386-402.

Görgüt, İ. \& Tuncel, S. (2017). Spor karakter ölçeğinin Türkçeye uyarlanması. SPORMETRE, 15(3), 149156.

Hellison, D. (2003). Teaching responsibility through physical activity. Champaign, IL: Human Kinetics.

Hodge, K. (1989). Character-building in sport: Fact or fiction? New Zealand Journal of Sports Medicine, $17(2), 23-25$.

Jang C.Y. (2013). Development and validation of the sport character scale. Doctoral Thesis, The University of Utah, USA.

Kavussanu, M. (2008). Moral behaviour in sport: Critical review of the literature. International Review of Sport and Exercise Psychology, 1(2), 124-138.

Kavussanu, M. \& Roberts, G.C. (2001). Moral functioning in sport: An achievement goal perspective. Journal of Sport and Exercise Psychology, 23(1), 37-54.

Sage, L. \& Kavussanu, M. (2007). The effects of goal involvement on moral behavior in an experimentally manipulated competitive setting. Journal of Sport and Exercise Psychology, 29(2), 190-207.

Qin, J., Leung, D. \& Shao, J. (2002). Estimation with survey data under nonignorable nonresponse or informative sampling. Journal of the American Statistical Association, 97(457), 193-200.

Silva, J. (1983). The perceived legitimacy of rule violating behavior in sport. Journal of Sport Psychology, 5, 438-448.

Tamminen, K.A., Holt, N.L., \& Crocker P.R.E. (2012). Adolescent athletes: Psychosocial challenges and clinical concerns. Child and Adolescent Psychiatry, 25, 293-300.

Teo, W. (2010). The effectiveness in measuring character development outcomes in Singapore schools through the character development award. (Doctoral Thesis), University of Durham.

Tiryaki, Ş. \& Gödelek, E. (1997). Spora özgü başarı motivasyonu ölçeğinin Türk sporcuları için uyarlama çalışması. 1. Uluslararası Spor Psikolojisi Sempozyumu Bildirileri, Bağırgan Yayınevi, 128.

Weinberg, R.S., \& Gould, D. (2015). Spor ve egzersiz psikolojisinin temelleri. Nobel Akademik, 579.

Willis, J.D. (1982). Three scales to measure competition-related motives in sports. Journal of Sport Psychology, 338-353.

Wooden, J., \& Jamison, S. (1997). Wooden a lifetime of observations and reflections on and off the court. Chicago, IL: Contemporary Books.

Yazıcıŏ̆lu, Y. \& Erdoğan, S. (2014). SPSS uygulamalı bilimsel araştırma yöntemleri (4. Baskı), Ankara: Detay Yayıncilık. 
Yıldız, Y. (2019). Bireysel ve takım sporcularının sportif karakterlerinin ve zekâ boyutlarının sportif başarı motivasyonları üzerine etkisinin incelenmesi. Doktora Tezi, Muğla S1tkı Koçman Üniversitesi, Sağlık Bilimleri Enstitüsü, Beden Eğitimi ve Spor Anabilim Dalı, Muğla. 